\title{
Ako sa stala Hipparchia z Maróneie slávnou filozofkou (historicko-filozofická interpretácia fragmentu SSR V I 1)
}

\section{How Hipparchia of Maroneia became a famous female philosopher (an analysis of fr. SSR V I 1 from historical-philosophical viewpoint)}

Jaroslav Cepko - Andrej Kalaš - Vladislav Suvák

\begin{abstract}
Abstrakt
Ciel'om článku je nanovo reflektovat' činnost' jednej z najslávnejších ženských filozofiek, Hipparchie z Maróneie. Naším zámerom je ukázat', prečo sa stala v porovnaní s inými ženami antiky taká významná a v mnohom signifikantná pre d'alší vývoj procesu ženskej emancipácie. Hlavným svedectvom je pre nás fragment SSR V I 1 od Diogena Laertského, ktorý kladieme do súvislosti s d’alšími antickými správami o Antisthenovi a raných kynikoch. Dve hlavné témy Diogenovho svedectva sú Kratétova svadba s Hipparchiou a spor Hipparchie s Theodórom. Vo výklade poukazujeme na momenty, v ktorých je filozofická osobnost' Hipparchie nadčasová a inšpiratívna aj pre súčasnost'.
\end{abstract}

\section{Kl'účové slová}

Hipparchia z Maróneie - Kratés z Téb - kynizmus - Theodóros z Kyrény - filozofia ako spôsob života - ženská emancipácia

\section{Abstract}

The aim of the paper is rethinking the activity of one of the most famous ancient women philosophers, Hipparchia of Maroneia and showing why she - compared to other women

Príspevok je súčast'ou riešenia grantového projektu VEGA 1/0094/20 Aristippos a sokratika. 
of Antiquity - became so significant in development of women's emancipation. The main testimony for us is the fragment SSR VI 1 by Diogenes Laertius, which we put in context with other ancient reports concerning Antisthenes and early Cynics. The two main themes of Diogenes' testimony are Crates' "marriage" to Hipparchia, and the controversy of Hipparchia with Theodorus. We reveal the aspect of Hipparchia's personality, which could be inspiring for modern era, as well.

\section{Keywords}

Hipparchia of Maroneia - Crates of Thebes - Cynicism - Theodorus of Cyrene - Philosophy as a Way of Life - Women's Emancipation

\section{1. Úvod alebo niečo o ženách-filozofkách v antike}

Keby sme sa podujali na zostavenie zoznamu žien-filozofiek, možno by sme boli prekvapení, ako málo ich pôsobilo počas dlhého trvania západnej kultúry. V staroveku by sme napočítali sotva dve desiatky mien a medzi nimi by sa našli aj postavy skôr fiktívne než historické (Diotima), alebo historické osobnosti, ktoré nadobudli filozofický charakter až v literárnych spracovaniach neskorších autorov (Aspasia). K dvom najznámejším filozofkám staroveku patria kynička Hipparchia pôsobiaca na začiatku helenistickej éry a novoplatonička Hypatia, ktorá žila na konci cisárskej doby. Medzi ich životmi leží celých sedem storočí.

Významným zdrojom správ o ženách vo filozofii, ale aj o kynikoch, ktorých filozofia nás bude v kontexte našej témy najviac zaujímat, sú pre nás Životy

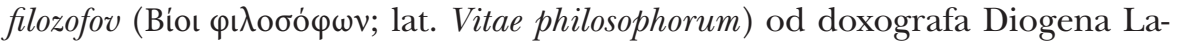
ertského. ${ }^{1}$ Diogenés žil na prelome 2.-3. st. po Kr. Obdobie neskorej antiky, v ktorom žil, pre historikov filozofie znamená, že väčšinu správ o raných kynikoch prevzal zo starších zdrojov (kynických, stoických, peripatetických), ktoré spracoval do samostatnej VI. knihy svojich Životov venovanej práve kynickej filozofii. Laertios pozná viacero žien, ktorým dáva atypický prívlastok

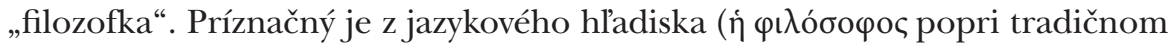

1 Kritické vydanie gréckeho textu (usporiadal Tiziano Dorandi): DIOGENES LAERTIUS. Lives of Eminent Philosophers... Slovenský preklad Miloslava Okála: DIOGENES LAERTIOS. Životopisy slávnych filozofov... Najnovší anglický preklad (2018) Pamely Mensch: DIOGENES LAERTIUS. Lives of the Eminent Philosophers...

2 Diogenove doxografie majú pre nás historickú hodnotu, ale vyžadujú si dôkladné preskúmanie založené na porovnávaní s inými starovekými správami. K prehodnoteniu Diogenových životopisov pozri bližšie MEJER, J. Diogenes Laertius and his Hellenistic Background... 


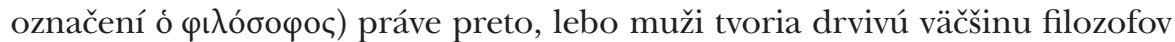
staroveku a starogréčtina si očividne nepotrebovala vytvorit samostatný termín pre ženu-filozofku pomocou prechylovacej prípony. ${ }^{3} \mathrm{Z}$ okruhu Akadémie sa Diogenés zmieňuje o dvoch ženách: Speusippovej milenke Lasthenii z Mantineie ( $\Lambda \alpha \sigma \theta \varepsilon \dot{v \varepsilon ı \alpha ~ M a v \tau ı v ı \kappa \eta ́) ~ a ~ o ~ n e z a ́ v i s l e j ~ a k a d e m i c k e j ~ f i l o z o f k e ~ A x i o t h e i ~ z ~ F l i u ́ n-~}$

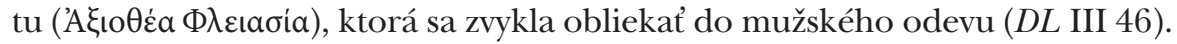
Ďalšou skupinou sú dcéry filozofov: Kloebúlova dcéra Kleobulina (DL I 91), Aristippova dcéra Areté ( $D L$ II 72 a 86) a dcéra Stilpóna z Megár, ktorej meno nám životopisec nezachoval (DL II 120). Do tejto skupiny by bolo azda možné zaradit aj Pythagorovu dcéru Damó a manželku Theanó, ktoré si osvojovali múdrost' pod dohladom otca a manžela (DL VIII 42). Filozofické milostné pomery Diogenés Laertský opisuje v prípade Aristippa a hetéry Laidy ( $D L$ II 74-75), ako aj Arkesilaových mileniek elidských hetér Theodoty a Fily (DL IV 40). Niekol'ko hetér je tiež spájaných s Epikúrovým spoločenstvom: Leontion (DL X 4, 5 a 7), Mammarion, Hédeia, Erótion a Nikidion ( $D L$ X 7). Epikúros mal mat pomer aj s vydatou žiačkou menom Themista ( $D L$ X 5).

S výnimkou platónskej filozofky Axiothey teda vidno, že všetky ostatné ženské postavy vo filozofii boli spojené rodinným (vztah otec-dcéra, výnimočne brat-sestra) alebo milostným putom s nejakým dominantným mužom-filozofom, ${ }^{4}$ od ktorého si pasívne a receptívne osvojujú filozofickú múdrosṫ. Hoci o týchto ženských postavách nevieme vela, oprávnene môžeme predpokladat, že vždy stáli v tieni dominantného muža-filozofa. Hipparchia je zo všetkých žien uvedených u Diogena Laertského nepochybne najslávnejšia. Prečo? Očividne preto, že z tieňa svojho filozofického spolupútnika vystúpila celkom zásadným spôsobom.

\section{Hipparchiin „psí sobáš” s Kratétom a kynické predstavy o manželstve}

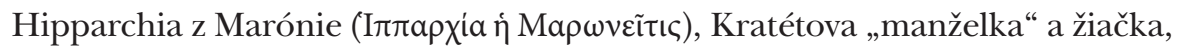
sestra Métrokla, d’alšieho Kratétovho žiaka (DL VI 94 [= SSR V L 1]), patrí k najznámejším ženským postavám v dejinách západnej filozofie, aj ked’ sa

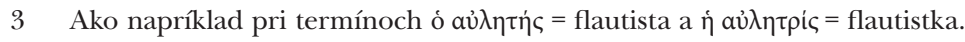

4 Por. DUTSCH, D. Dog-love-dog..., s. 523. 
o nej zachovalo len zopár biografických anekdot. ${ }^{5}$ Hipparchiu spája s filozofiou, emancipuje ako ženu a teda robí ju významnou filozofkou predovšetkým spôsob, akým sa stala Kratétovou žiačkou a manželkou - spôsob, ktorý povýšila

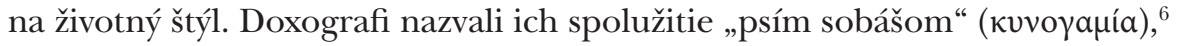
čo je výraz, ktorý možno preložit aj ako „psie manželstvo“ alebo „kynické manželstvo“. Jeho podstata spočíva v niečom inom, ako by sme si pomysleli, keby sme mechanicky spojili naše predstavy o spolužití psov s predstavami

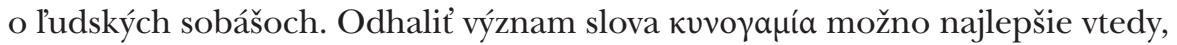
ked' si uvedomíme dva naznačené významy tohto slova: povaha kynického

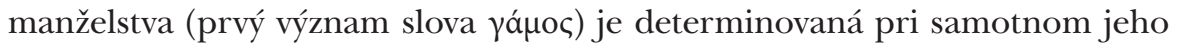
zrode, teda pri (nadovšetko slobodnom) „kynickom“ rozhodnutí partnerov žit spolu, teda realizovaním kynického „sobáša“ či „kynickej“ svadby (druhý

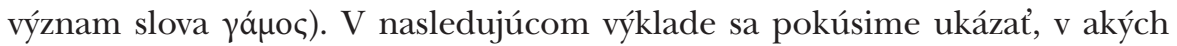

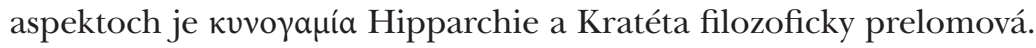

Ked’ sa pozrieme na ich zväzok z pohladu kynickej filozofie, ukáže sa, že „manželstvo“ by malo byt’ v kynickom priestore skôr výnimkou než pravidlom. Kynik je predsa odkázaný na život v osamelosti - žije ako tulák a žobrák, putuje z miesta na miesto a hlása skromný spôsob života založený na súlade s prírodou. Potulný kynický kazatel' by len tažko dokázal zosúladit každodennú neistotu svojej existencie (nevie, kde bude spat', nevie, čo bude jest') s uspokojivým zabezpečením manželky a rodiny. Z tohto hladiska je sobáš Kratéta s Hipparchiou v kynickom kontexte jednoducho prekvapivý a atypický.

Ked' vezmeme do úvahy Antisthenove a Diogenove názory na manželstvo, naozaj zistíme, že títo kynici ho považujú skôr za prekážku než za prostriedok dosiahnutia dobrého života. ${ }^{7}$ Po hlbšom preskúmaní však Antisthenove a Diogenove názory nie sú v úplnom protiklade s tým, čo hovoria príbehy o Kratétovi a Hipparchii. Kratés napríklad rešpektuje a napíňa antisthenovskú zásadu, podla ktorej intímny vztah medzi mužom a ženou má byt’ vý-

5 Na zlomky sókratovských autorov odkazujeme podla číslovania, ktoré zaviedol Gabriele Giannantoni, Socratis et Socraticorum reliquiae (skratka SSR). Táto zbierka nám zároveň poslúžila ako kritická edícia antických textov, na ktoré v štúdii odkazujeme.

6 Pozri: Suid., s. v. Kratés [= SSR V H 19], kde sa uvádza, že sám Kratés nazval svoj sobáš

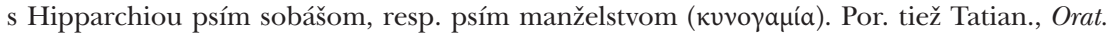
ad Graec. 3, 3 [= SSR V H 23], kde krestanský apologéta Tatianus Sýrsky z 2. storočia po Kristovi odsudzuje psie manželstvo ako niečo nemorálne práve preto, že mu chýba inštitucionálny rámec, taký dôležitý pre krestanstvo.

Por. SSR V A 57; V A 82; V B 126; V B 200; V B 297. 
sledkom vzájomného súhlasu. ${ }^{8}$ Okrem toho Antisthenés tvrdí, že iba mudrc skutočne vie, koho sa oplatí milovat, hoci nás vzápätí trochu prekvapí jeho názor, že ak sa mudrc ožení, tak len kvôli plodeniu detí, majúc styk s tými najkrajšími ženami. ${ }^{9}$ Zásada zmysluplnosti manželstva z hladiska plodenia zdarného potomstva nie je v gréckom kontexte nijako prekvapujúca. Ak pripustíme, že už Gréci si uvedomovali elementárne zásady dedičnosti, výber najkrajšej manželky vel’mi dobre korešponduje so snahou dosiahnut krásne, teda zdarné potomstvo.

Kynikovi Diogenovi prisudzuje jeho menovec Laertios o niečo radikálnejšie názory:

Ženy majú byt spoločné, pričom Diogenés vôbec neuvažoval o svadbe, ale len o tom, že muž sa má milovat’ s akoukolvek ženou, ktorú presvedčí. Spoločné budú preto vraj aj všetky deti. ${ }^{10}$

Vyjadrenie, že ženy a deti majú byṫ „spoločné“, treba chápał zrejme tak, že Diogenés neuznáva vžitú predstavu, podla ktorej sú žena a deti „vlastníctvom“ muža. K pohlavnému styku a spoločnému životu (čo sú dva významy slovesa бvveĩval) by mali partneri dospiet na základe „presviedčania“. V tom, že muž má „presviedčat" a žena má byt’ „presvedčená“, vidí D. Dutschová narážku na to, že sexuálna aktivita v heterosexuálnom vztahu má byt podla kynika Diogena modelovaná podla výchovného vztahu medzi milujúcim

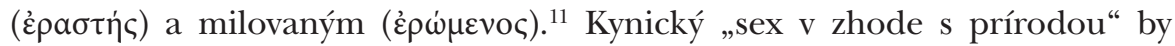
teda neznamenal prelomenie akýchkolvek zábran a povolenie uzdy pudom. ${ }^{12}$ Je prirodzený práve v tom, že je etický („život v súlade so zdatnostou“), to znamená založený na slobodnom súhlase. Ide o prejav kynického opovrhovania vžitými mravmi v prospech hlbokého vnútorného étosu. A práve tento hlboký étos slobodného rozhodnutia pre vstup do vztahu bude základným pilierom emancipácie Hipparchie. Tá - ako zakrátko uvidíme v zlomku SSR V I 1 z Diogena Laertského - sa sama rozhoduje pre Kratéta vo chvíli, ked'

\footnotetext{
8 Por. SSR V A 55.

$9 \quad D L$ VI 11 [= SSR V A 58].

$10 \quad D L$ VI 72 [= SSR V B 353].

11 DUTSCH, D. Dog-love-dog..., s. 250-251.

12 O tzv. kynickom antihedonizme a hedonistickom asketizme pozri štúdiu: KALAŠ, A. Diogenov postoj k l'udskej sexualite..., s. 119-130.
} 
sa pred ňu postavil celkom nahý a dáva jej možnost̉ slobodného rozhodnutia vyrieknuc prorocké slová:

Toto je tvoj ženích a takýto má majetok. Podla toho sa rozhoduj. ${ }^{13}$

V tomto kontexte si môžeme všimnút aj iný - skôr sociálny - aspekt celej situácie. Môžeme povedat, že kynické „manželstvo“ je odmietnutím inštitúcie manželstva ako jedného z pilierov budovania obce či štátu v duchu starej filozofickej maximy: slobodní l’udia nepotrebujú inštitúcie a zákony, aby konali dobre a krásne. Pre uzavretie platného manželstva nepotrebujú akt posvätenia obce, ale stačí im ich autentické a slobodné rozhodnutie.

Kritický postoj Kratéta a Hipparchie voči inštitúcii manželstva by dosvedčovali viaceré anekdoty, dokonca aj tie, ktoré mohli byt literárnym pretvorením pôvodných kynických príbehov. Eratosthenés z Kyrény (276-195 pred Kristom) hovorí, že Kratés mal s Hipparchiou syna Pasikla, ktorého, ked' dospel, priviedol ho do domu nejakej hetéry a povedal mu, že takto si jeho otec predstavuje svadbu. ${ }^{14}$ Príbeh o tom, ako mal Kratés poučit svojho syna o podstate manželstva, pochádza z Eratosthenovho spisu $O$ komédii, preto je celkom možné, že jeho zdrojom bolo nezachované komické stvárnenie Kratéta - podobne ako v prípade Menandrových Dvojičiek, kde sa objavuje narážka, že Kratés mal poskytnút vlastnú dcéru na tridsatdňové „skúšobné manželstvo“. ${ }^{15}$ To, že terčom posmechu bol v prvom rade sám Kratés spolu

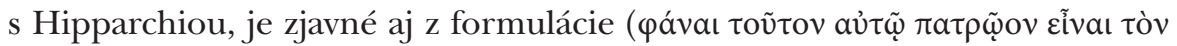

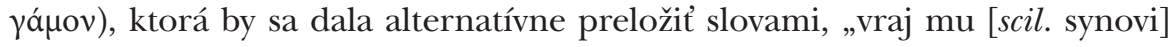
povedal, že takýto bol aj sobáš jeho otca“. Každopádne môžeme povedat', že z Eratosthenovej anekdoty cítił ironický odstup kynika od manželstva ako štátnej inštitúcie, ktorý mohol byṫ pôvodným motívom komického prerozprávania príbehu o „psom sobáši“. Všetko to opät svedčí v prospech tézy, že Kratétov a Hipparchiin koncept manželstva bol celkom iný - neformalistický a neinštitucionalistický - a hlavne založený na autenticite vlastného sebavyjadrenia.

Kynici nadviazali podla doxografov na Antisthena („najvernejšieho Sókratovho žiaka“) a ten vraj rozvíjal Sókratovo učenie spôsobom, ktorý mal mat blízko k jeho názorom na život. Potvrdením opísaného kynického pohladu

$13 D L$ VI 96, 8-10 [= SSR V I 1].

14 Eratosthenes $a p$. DL VI 88-89 [= SSR V H 19].

15 DL VI 93 [= SSR V H 26]. 
na manželstvo by teda mohol byt polemický postoj $\mathrm{k}$ inštitúcii manželstva, ktorý siaha cez Diogena a Antisthena až k Sókratovi. V Platónovej Obrane 36b-c Sókratés uznáva, že pre svojich spoluobčanov asi nie je vzorným manželom, ktorý sa stará o „vlastné veci“ (majetok, rodina, čest', sláva). Muž by mal dbat pri výbere ženy skôr na užitočnost̉ tohto zväzku než na ženskú krásu alebo na predstavy obce.

V podobnom duchu hovorí antisthenovská pasáž v Xenofóntových Spomienkach:

Viac než o to [rozkoš, ktorú prináša pohlavný styk] dbáme o to, ktoré ženy by boli schopné dat nám najlepšie deti; tieto si berieme za manželky a zakladáme s nimi rodinu; muž živí matku svojich budúcich detí a pre budúcich potomkov pripravuje všetko, čo považuje za užitočné pre ich život. ${ }^{16}$

\section{H. Maier na okraj tejto pasáže poznamenáva:}

To, že tento Antisthenov názor pochádza priamo od Sókrata, je pravdepodobnejšie, než to, že by zavrhnutie manželstva logicky vyplývalo z jeho vlastného presvedčenia - čo vyvodí až jeho žiak Diogenés. ${ }^{17}$

Problematizácia manželstva mala medzi sókratovcami prvej generácie viacero podôb. Antisthenés mohol zastávat jednoduchý názor, že tak, ako všetky záležitosti života, aj vhodný výber partnerky si vyžaduje filozofické vzdelanie - bez vzdelania sa môžeme rozhodnút zle. Takýto postoj by sa zakladal

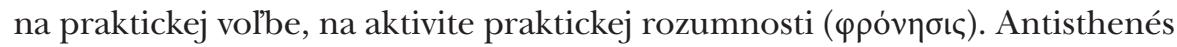
mohol svojím vyjadrením zároveň parodovat Platónovu eugenickú teóriu rozmnožovania, ako je vyjadrená v Ústave. ${ }^{18}$

Zdá sa, že Kratés a Hipparchia posunuli pôvodný sókratovsko-antisthe-

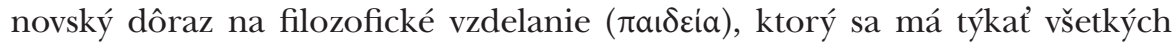
záležitostí života, teda aj manželstva, smerom k slobodnému rozhodovaniu, ktoré by mali l’udia uplatňovat bez ohladu na konvenčné názory alebo zásady

16 Xenoph., Mem. II 2, 4.

17 MAIER, H. Sokrates..., s. 412.

18 Por. Resp. 459d-e: „Najlepší muži majú - a to na základe spoločnej dohody všetkých zúčastnených - obcovat’ s najlepšími ženami čo najčastejšie, zatial' čo najhorší muži s najhoršími ženami presne naopak; a potomkovia prvých majú byt vychovávané, zatial' čo deti druhých nie, pokial má byt’ stádo čo najdokonalejšie“ (preklad autorov štúdie); vid’ taktiež Resp. 546d. Platón tu teda pripodobňuje rozmnožovanie ludí k rozmnožovaniu zvierat. 
obce. Dosvedčujú to neskoršie stoické diskusie o úlohe manželstva, ktoré sú zjavne ovplyvnené kynizmom. ${ }^{19}$ Musonius Rufus a Epiktétos zastávajú rôzne názory na manželstvo, pričom každý z nich považuje Kratéta za príklad toho, aký postoj by sme mali zaujat' k zväzku muža a ženy, v ktorom má jednoznačne dominovat princíp slobody.

Musonius sa zamýšla nad tým, či je život so ženou prekážkou na ceste filozofovania, a konštatuje, že to nebolo žiadnou prekážkou pre Pythagora, pre Sókrata, ani pre Kratéta:

Ved' všetci títo vraj žili so ženou a nik by nemohol uviest̉ lepších filozofov, ako boli oni. Kratés sa oženil napriek tomu, že nemal dom, nábytok a ani žiaden iný majetok. So svojou ženou trávil dni aj noci v aténskych verejných stĺporadiach. ${ }^{20}$

Musonius odpovedá - ako stoik - na otázku, ktorú nastoluje titul jeho spisu (Či je manželstvo prekážkou vo filozofovani), že manželstvo je v zhode s prírodou, a preto nemôže byt prekážkou pri vedení filozofického spôsobu života. Príroda rozdelila l’udský rod na dve pohlavia a vložila do srdca muža i ženy špecifický pôvab a vzájomnú prítažlivost. Vd’aka ich telesnému spojeniu sa rodia deti, a tak ludský rod pretrváva v čase. Toto rozdelenie pohlaví zároveň ukazuje, že človek nemá žit iba sám pre seba, ale má sa starat aj o druhých v rámci siete služieb a povinností. Ludstvo podla Musonia predstavuje v tomto kontexte spoločenstvo podobné včeliemu úlu. Rozdelenie l’udského rodu na dve pohlavia a potom spájanie týchto pohlaví prostredníctvom vzájomnej prítažlivosti má dvojaký aspekt, ktorý Musonius vyjadruje použitím dvoch

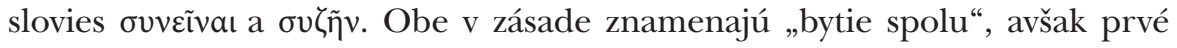
konotuje sexuálny styk, druhé vzájomné zdielanie života. Muž a žena sú tak

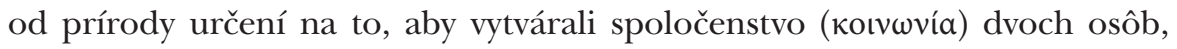
aby žili ako pár. ${ }^{21}$

Ďalší slávny stoik, Epiktétos (okolo 50 - okolo 135 po Kristovi) naopak pochybuje, či sa filozofický spôsob života dá zlúčit s manželstvom. Kynický filozof sa podla neho neožení a nezaloží si rodinu, pretože by mu to prekážalo v napĺňaní jeho misie ako posla, ktorý prináša l’ud’om posolstvo bohov.

19 O vztahu raného stoicizmu a kynizmu pozri štúdiu KALAŠ, A. Vplyv kynizmu na stoicizmus..., s. 405-430.

20 Muson. 15 p. 70, 11-17, 5 Hense [= SSR V H 20].

21 M. Foucault identifikuje u Musonia prvé stopy recipročnej manželskej morálky, ktorá sa od stoikov prenesie aj do krestanstva (FOUCAULT, M. Subjectivity and Truth..., s. 162-163). 
Na námietku, že Kratés, určitým spôsobom „domáci bôžik“222 a najlepší príklad spoločenskej služby l’ud’om, ${ }^{23}$ bol napriek tomu ženatý, Epiktétos odpovedá nečakanou poznámkou o osobnosti Hipparchie:

Kratés sa oženil [...] stalo sa to z lásky a tou ženou bol vlastne druhý Kratés. ${ }^{24}$

Epiktétovo vysvetlenie má zrejme zdôraznit, že Kratés sa oženil s niekým, kto bol ako on sám, t. j. s niekým, kto vyznával rovnaký spôsob života. Z tohto hladiska je „manželstvo“ skôr najvyššou formou priatel'stva, zväzkom, v ktorom je priatel’ pre priatel’a „druhým ja“. Aristotelés nazval takéto priatel’stvo spoločenstvom zdatne konajúcich ludíi. ${ }^{25}$ Dokonalý priatel’ je niekto, ku komu má druhý taký istý vztah ako k sebe samému. Aristotelovo chápanie priatel'stva by sme však mali dat aj do kontextu s jeho politickou náukou, ktorá vidí v človeku tvora nepatriaceho iba sebe samému, ale obci. ${ }^{26}$ Naproti tomu pre Kratéta a Hipparchiu je priatel'stvo vecou osobnej vol'by, v ktorej nezohrávajú politické ani iné vonkajšie okolnosti významnejšiu prekážku. Zvrchovane slobodnou a nadovšetko zdôvodnenou volbou partnera je v zmysle tejto logiky tá, ktorá sa v partnerovi rozhoduje pre seba samého, ked' v tom druhom volí „alter ego“, čím človek akoby sebapotvrdzuje sám seba - presnejšie svoju prirodzenost. ${ }^{27}$

Poznamenajme, že v Grécku 5. a 4. storočia pred Kristom sa erotický vzṫah dával do úzkeho vztahu s výchovou a odovzdávaním vedomostí. To platilo dokonca aj pre „štandardné“ manželstvo, v ktorom jedným z poslaní muža (zvyčajne staršieho aj o desať či dvadsat̉ rokov) bolo vychovávat̉ svoju manželku. Pekný príklad takejto praxe nachádzame aj v sókratovskej literatúre, kde sa

22 Por. Apul., Flor. 22 [= SSR V H 18]: lar familiaris.

23 Por. Plutarch., Quaest. conv. II 1, 6 p. 632 E [= SSR V H 18]: „Filozofa Kratéta nazývali Otváračom dverí, pretože ho v každých dverách vítali s úctou a priatel'ským pozdravom. Aj pokarhanie, ktoré sa robí s láskou, môže byt celkom príjemným žartom. “Všetky antické pramene označujúce Kratéta za „Otvárača dverí“ sa zhodujú v názore, že medzi Aténčanmi mal povest príjemného spolubesedníka. Týmto sa Kratés odlišoval tak od Diogena známeho svojou hryzúcou uštipačnostou (por. SSR V B 61, 143, 145, 487), ako aj od neskoršieho stereotypu kynika ako zachmúreného moralizujúceho pouličného kazatel'a, u ktorého je špinavý a spustnutý výzor iba pokryteckou pózou.

24 Epictet., Dissert. III 22, 76 [= SSR V H 20].

25 EN 1166a31, 1169b6, 1170b6.

26 Pol. 1337a28-29.

27 Por. Antisthenove slová o mudrcovi ako priatel'ovi toho, kto mu je podobný; DL VI 105 [= SSR V A 99]. 
táto myšlienka objavuje ako nosná téma Sókratovho rozhovoru s Ischomachom v 7. časti Xenofóntovho Oikonomika. Okrem toho erotika zohrávala významnú rolu aj vo vztahu medzi vychovávatelom a vychovávaným dospievajúcim

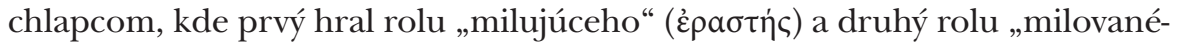

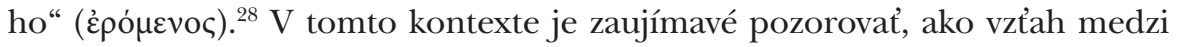
Kratétom a Hipparchiou na tieto témy na jednej strane nadväzuje a na strane druhej ich v duchu kynickej „falšovatel'skej“ optiky subvertuje. ${ }^{29}$ Pozrime sa preto, ako je to vykreslené v našom hlavnom svedectve o „manželskom zväzku“ Kratéta a Hipparchie. Náš výklad bude pritom stále smerovat k tomu, aby sme poukázali na to, v čom bola Hipparchia ako osobnost̉ jedinečná.

\section{Hipparchia, zlomok SSR V I 1 (grécky text a slovenský preklad)}

V Giannantoniho zbierke Socratis et Socraticorum Reliquiae sa pod menom Hipparchia uvádzajú len tri plnohodnotné fragmenty. Prvý z nich, ktorý citujeme v gréckom origináli aj vlastnom preklade, je rozsahom aj informačným obsahom najväčší. Poskytuje nám preto dostatočný pramenný materiál na historicko-filozofickú sondu do osobnosti jedinečnej filozofky staroveku. Prostredníctvom tejto sondy sa pokúsime čitatela presvedčit o tom, prečo si Hipparchia zaslúži, aby sme na ňu nikdy nezabudli.

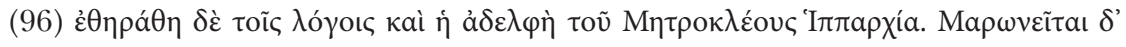

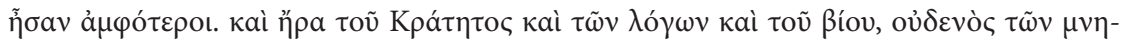

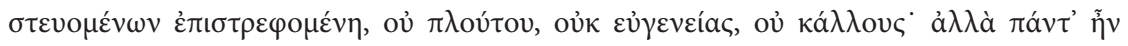

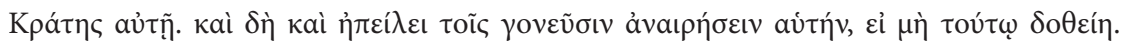

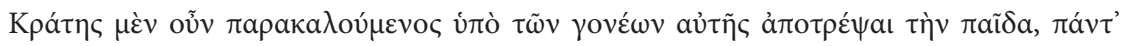

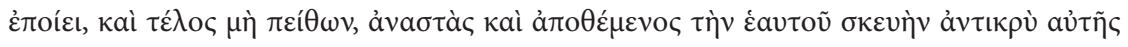

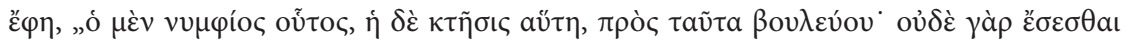

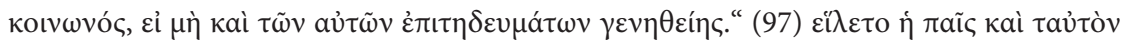

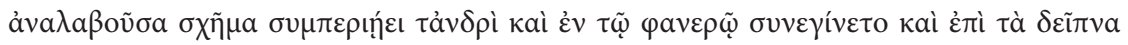

28 Por. ZELINOVÁ, Z. Paideia v sokratovskej filozofii..., s. 134-157.

29 Pre pôsobenie kynikov sa v antike zaužívala príznačná charakteristika, že „falšujú mravy“

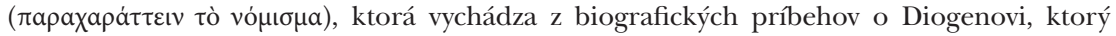
falšoval peniaze v rodnej Sinópe (výraz vó $\mu$ เ $\mu$ a môže znamenat tak „mincu“, „obeživo“, ako aj zaužívaný „zvyk“, „mrav“, „pravidlo“; por. zl. SSR V B 2). O význame, aký mala paideia v kontexte sokratiky a kynizmu, por. ZELINOVÁ, Z. Kynická paideia..., s. 107-118. 


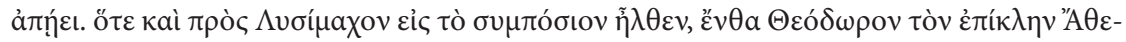

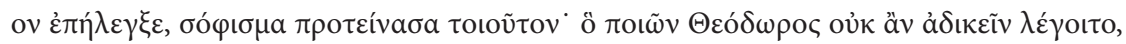

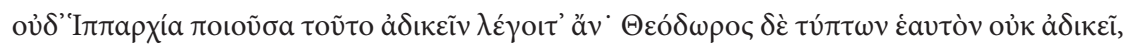

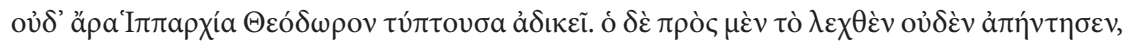

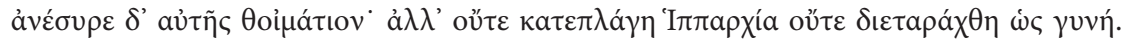

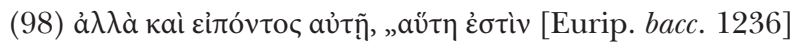

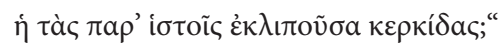

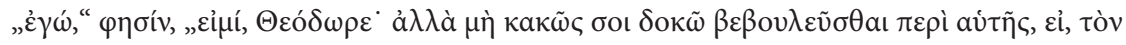

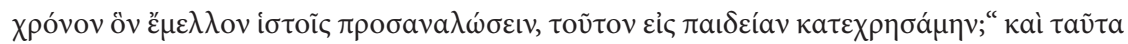

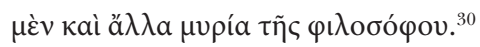

(96) Slová dostali do manželstva aj Métrokleovu sestru Hipparchiu. Obaja súrodenci pochádzali z mesta Maróneia. Hipparchia bola zamilovaná do Kratétových myšlienok a do spôsobu života, ktorý viedol. Ostatných pytačov si vôbec nevšímala. Nelákalo ju ich bohatstvo, urodzený pôvod ani fyzická krása. Kratés bol pre ňu skrátka všetkým. Rodičom sa dokonca vyhrážala, že spácha samovraždu, ak sa jej zaňho nedovolia vydat. Rodičia dievčiny preto požiadali Kratéta, aby ju od sobáša odhovoril. Filozof urobil všetko, čo bolo v jeho silách, aby Hipparchiu od seba odhovoril. Ked' sa mu to nepodarilo, postavil sa pred ňu celkom nahý a povedal: „Toto je tvoj ženích a takýto má majetok. Podla toho sa rozhoduj. Ale uvedom si, že mojou spoločníčkou sa staneš len vtedy, ak budeš viest̉ rovnaký život ako ja.“ (97) Dievčina sa zaňho rozhodla vydat, obliekla si taký istý odev a svojho muža všade sprevádzala. Spolu chodili na hostiny a súložili na verejných miestach. Ked’ raz prišla na bohatú hostinu, ktorú usporiadal Lysimachos, filozofa Theodóra prezývaného „Bezbožník“ si doberala takouto sofizmou: „Ak Theodóros vykoná čin, za ktorý ho nik nemôže vyhlásit za nespravodlivého, za nespravodlivú nemožno označit ani Hipparchiu, ktorá vykoná to isté. Theodóros nekoná nespravodlivo, ak bije sám seba. Teda ani Hipparchia nekoná nespravodlivo, ak bije Theodóra.“ Na tieto slovách filozof neodpovedal. Urobil len to, že Hipparchii nadvihol šaty. Hoci bola žena, vôbec sa nezlakla ani nezahanbila. (98) Ked' sa jej spýtal:

„Toto je tá,

[...] ktorá opustila tkáčske člnky na krosnách?"31

$30 \quad$ DL VI 96-98.

31 Euripid., Bacc. 1236. 
Hipparchia mu odpovedala: „Áno, Theodóros, som to práve ja. Alebo sa ti zdá, že som urobila chybu, ked' som sa rozhodla na vzdelanie využit všetok čas, ktorý som mala strávit pri krosnách?“ Takéto a ešte mnohé d’alšie výroky vyslovila filozofka Hipparchia.

\section{Historicko-filozofická interpretácia zlomku SSR V I 1 alebo niekol'ko pokusov odpovedat' na otázku, prečo je Hipparchia "iná" ako ostatné}

Všimnime si najskôr, v akom kontexte je Hipparchiin životopis u Diogena Laertského vsadený do životopisu Kratéta. Ten je prerušený najprv odbočkou k Métroklovi (DL VI 94-95a), pokračuje výpočtom iných Kratétových žiakov (DL 95b), nasleduje náš zlomok - teda životopisná vsuvka o Métroklovej sestre a Kratétovej manželke a žiačke Hipparchii - a napokon celá VI. kniha končí stručnou informáciou o Kratétovej smrti a jeho hrobe. ${ }^{32}$

Prvá čast̉ Hipparchiinho životopisu (DL VI 96, 1 - 97, 1) sa venuje tomu, ako sa spoznala s Kratétom, zamilovala sa doňho i do jeho učenia - presnej-

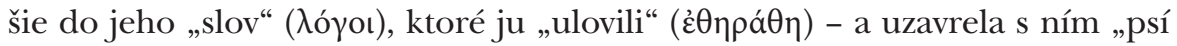
sobáś“, presnejšie „vybrala si ho“ ( $\left.\varepsilon \iota^{\prime} \lambda \varepsilon \tau o\right)$. Príbeh o Hipparchiinej konverzii je zároveň akousi demonštráciou toho, že filozofia znamená pre ňu aj pre Kratéta spôsob života, ked’že výraz pre filozofické myšlienky ( $\lambda$ ójoı) a život (ßíoc) v našom texte bezprostredne susedia. ${ }^{33}$ Kratés bol teda pre ňu prítažlivý svojou životnou filozofiou či filozofickou praxou. Nebol to žiaden teoretik, ale očividne vyzretý človek, ktorý presne vedel, čo chcel a čo nechcel od života. Druhá čast' (DL VI 97, 3 - 98, 7) referuje o anekdote, ktorej protagonistkou je sama Hipparchia ako filozofka. Táto čast potvrdzuje, že Hipparchia nielen žije ako kynička, ale svoje názory a postoje dokáže aj obhájit ako každý iný (mužský) filozof.

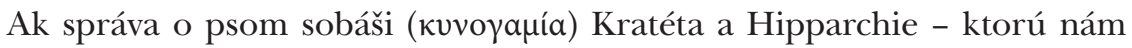
okrem Diogena Laertského reprodukujú aj Apúleios, Sextus Empiricus, Menandros v Dvojičkách a lexikón Súdas ${ }^{34}$ - hovorí pravdu, verejné erotické ob-

32 Ohladom problémov týkajúcich sa štruktúry Kratétovho životopisu por. GOULET-CAZÉ, M.-O. Une liste de disciples de Cratès..., s. 247-252.

33 Por. výraz toũ ßíov v Diogenovej správe: Hipparchia sa zamilovala do Kratétových „myšlie-

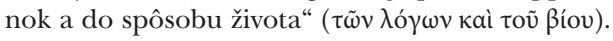

34 Apul. flor. 14 [= SSR V H 24]; Sext. Emp., Pyrrh. hypot. I 14, 153 [= SSR V H 21]; Menandros $a p$. DL VI 93 [= SSR V H 26]; Suid., s.v. Kratés [= SSR V H 19]. 
covania tohto páru sa museli odohrał po roku 320 pred Kristom, pretože Theofrastos, u ktorého sa učil Métroklés pred tým, ako sa zoznámil s Kratétom, prevzal vedenie peripatetickej školy v roku 323 pred Kristom. ${ }^{35}$

Vel'ký osudový príbeh vztahu Kratéta a Hipparchie teda začína tým, že ju pritiahli „slová“, „myšlienky“ ( $\lambda$ ójoı). Z kontextu nie je zrejmé, o aké „slová“ malo íst'. Z toho, že Hipparchia je bližšie určená ako „Métroklova sestra“, by bolo možné usúdit, že onými „slovami“ mohol byt rozhovor medzi Kratétom a Métroklom, vd’aka ktorému sa Métroklés po neblahom incidente (vypustenie vetrov pri nejakej filozofickej debate) ${ }^{36} \mathrm{v}$ Theofrastovej škole stal nasledovníkom Kratéta a opät získal sebavedomie a zmysel života. ${ }^{37}$ Kratés svojimi múdrymi, konvencie lámajúcimi a nadovšetko láskavými slovami adresovanými vlastnou hanbou a mienkou l'udí zlomenému Métroklovi musel mimoriadne učarovat Hipparchii, ktorá sa do neho hned' zalúbila. V tom prípade by Hipparchia bola prítomná pri tomto ukážkovom kúsku kynickej „rétoriky“ spájajúcej slová s prirodzenými telesnými prejavmi. ${ }^{38}$ Takouto kynickou „rétorikou tela" bude koniec koncov i jej kynogamický vztah s Kratétom, ako aj rozhovor s Theodórom, o ktorom budeme hovorit trochu neskôr. V každom prípade to, čo Hipparchii na Kratétovi imponovalo, nebola kynická prísnost' diogenovského typu, ale vlúdnost̉ filozofa a príjemného spoločníka, ktorý zmieroval l’udí a v každom dome bol vítaným hostom. ${ }^{39}$

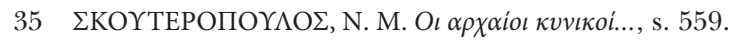

$36 D L$ VI 94 [= SSR V L 1]. Opisuje sa tu škandalózny incident, ked’ Métroklés pri nejakej filozofickej debate v peripatetickej škole nedokázal zadržat' vetry: „... z hanby a strachu celé dni nevychádzal z domu. Mal v úmysle držat hladovku a takto zomriet. Kratés, ktorý sa to dozvedel, sa dal pozvat’ a prišiel k nemu na návštevu. Potom sa zámerne najedol nejakých strukovín a medzitým sa pokúšal múdrymi slovami presvedčit Métrokla, aby si neurobil nič zlé. Argumentoval, že ak by zo seba prirodzenou cestou nevypustil tie plyny, bola by z neho obluda. Napokon aj on sám urobil to, za čo sa Métroklés tak hanbil. Takýmto spôsobom ho Kratés povzbudil a dodal mu mužného ducha. Jeho útecha sa zakladala na podobnosti vykonaných činov. Odvtedy bol Métroklés Kratétovým žiakom a stal sa vynikajúcim filozofom."

37 Por. zlomok SSR V H 44. V tejto Telétovej správe sa zasa uvádza, že Métrokla prenasledoval v Theofrastovej škole strach, že zomrie od hladu, ale ked' sa pridal ku Kratétovi, obavy ho opustili: „Z Métrokla sa zrazu stal jeden prostý a priamy človek, ktorému ku štastiu stačil ošúchaný plášt, jačmenný chlieb a zelenina, ktorú našiel v záhrade. Spôsob života, ktorý viedol, ho plne uspokojoval a všetko to, čo bolo predtým, mu vôbec nechýbalo.“

38 Por. BRANHAM, R. B. Defacing the Currency..., s. 98.

39 Pripomíname (podrobnejšie pozri pozn. 24), že pre tieto ludské vlastnosti l’udia prezývali Kratéta „otváračom dverí“ - teda človekom ktorý bol všade vítaným hostom. Možno aj toto bola vlastnost', ktorá budúcej manželke - azda túžiacej po sociálnom kontakte - mohla na Kratétovi zaimponovat. 
Na príbehu Kratéta a Hipparchie je tiež markantné, ako v ňom dochádza k inverzii vzţahu milujúceho a milovaného. Nie je to Kratés, kto sa zamiluje, hoci práve jemu ako mužovi a staršiemu by mala pripadnút táto rola. Životopisec však upozorňuje, že Hipparchiina láska ku Kratétovi mala za svoj pred-

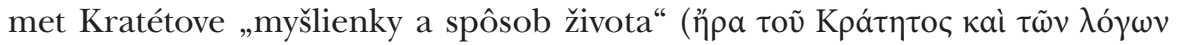
kaì toṽ ßíov), teda milujúcou, aktívnou zložkou vztahu, bola práve ona, čo dokazuje aj činný rod imperfekta gréckeho slovesa ñ $\rho$ („,milovala“, „túžila“). Nielen to, výbornou adeptkou na aktívny mód kynického života z nej robí aj jej pohŕdanie konvenčnými motívmi k láske - nepritahuje ju ani bohatstvo, ani spoločenský status, ani vzhl’ad pytačov. Podobne je to aj u Kratéta: hoci sa mu práve ponúka možnost̉ oženit sa s krásnou, mladou dievčinou z dobre situovanej rodiny, preukazuje voči tejto pre iných atraktívnej per-

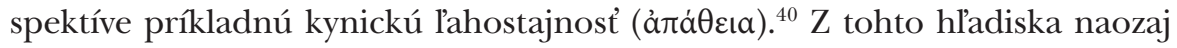
platí Epiktétova poznámka, že sa našli dve osoby rovnakého hodnotového nastavenia, a „Kratés si berie druhého Kratéta“. ${ }^{41}$ Kratés dokonca zachádza tak d’aleko, že namiesto toho, aby si dievča „nahováral“, snaží sa Hipparchiu od jej zámeru odhovorit, zdráha sa, uniká pred ňou. Toto je - mimochodom - postoj, ktorý sa v pederastickom vztahu vychovávatela a vychovávaného očakával od mladého chlapca, „miláčika“, voči svojmu staršiemu „milovníkovi“. Kratétov postoj zdráhania sa láske nám tak skôr pripomína tradičný či „konvenčný“ postoj „cudnej“ ženy, ktorá sa zdráha alebo vyberá si z radu pytačov (azda Penelopa u Homéra). Možno aj toto je jeden z typicky kynic-

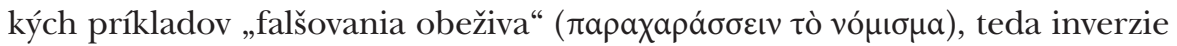
všetkého konvenčne zaužívaného a etablovaného. Hipparchiina zamilovanost’ pripomína sókratovský topos o láske žiaka k svojmu vychovávatelovi, ktorého najznámejšiu verziu možno nájst’ v opise Alkibiadovho vzt̉ahu k Sókratovi v Platónovom Sympósiu (215a-219d). Kratés rovnako ako Sókratés neoplýva prítažlivým vzhladom; Hipparchia a Alkibiadés naopak majú množstvo nápadníkov a okrem krásy prevyšujú filozofa aj bohatstvom a spoločenským postavením. Hipparchia však dokáže prekonat konvenčné hodnoty a zalúbi sa do filozofie. Povedané slovníkom Platónovho Symposia, jej láska prekračuje čisto telesnú dimenziu (210a-212a), a preto je láskou filozofickou. V podobnom duchu by sme mali interpretovat Sókratove ironické slová na adresu

40 Por. zl. SSR V H 27: „Kratés zámerne nadával prostitútkam, aby sa tak cvičil v používaní nadávok aj inde." Kynik sa cvičí nielen v parrhésii, ale aj v tom, aby dokázal znášat nadávky a ponižovanie s čo najväčšou l'ahostajnostou; por. ZELLER, E. Die Philosophie der Griechen..., s. 320, pozn. 6 .

41 Por. Epict., Dissert. III 22, 76 [= SSR V H 20]. 
Antisthena, ktorý sa mu vyznal z vášnivej lásky (hovorí, že svoje vnútorné bohatstvo získal od Sókrata):

O tej tvojej láske ku mne radšej pomlčme [...] netýka sa totiž duše, ale krásy tela. ${ }^{42}$

Napokon sa Kratés pri tomto odhováraní uchýli k šokujúcemu gestu - úplnému obnaženiu sa, ktoré je na jednej strane demonštráciou jeho chudoby a zároveň testom, ako sa Hipparchia zachová v situácii, ktorá zvyčajne prebúdza pocit zahanbenia. A všimnime si, že nádejná filozofka v tomto teste obstojí ovela lepšie ako iný Kratétov žiak - Zénón, ktorý sa nevie ubránit rozpakom, ked’ mu po nohách steká šošovičná kaša z rozbitého hrnca. ${ }^{43}$ Sobáš Kratéta a Hipparchie je teda zároveň iniciáciou do kynického spôsobu života,

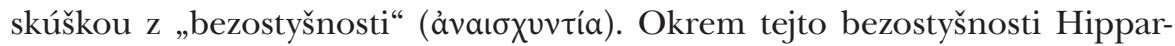
chia demonštruje aj vytrvalost’ v svojom odhodlaní. V protiklade k bežnej

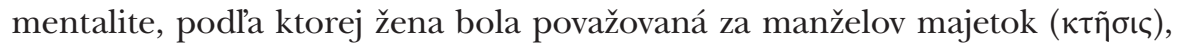
tu je to naopak Kratés, ktorý sa pri svojom obnažení vystavuje Hipparchii ako nejaký tovar, podobne ako sa vystavovali pri dražbe otroci. Ide teda aj o inverziu v rovine vlastníckych a mocenských vztahov medzi manželmi. D. Dutschová upozorňuje v tejto súvislosti na podstatný princíp kynickej sexuálnej etiky: ${ }^{44}$ podl’a Diogena zo Sinópy muž a žena majú spolu žit iba po vzájomnom súhlase, „prehováraní“ či „presviedčani“. ${ }^{45}$ Preto obnažený Kratés kladie svoju podmienku (prijatie rovnakého spôsobu života) a vyzve Hipparchiu,

42 Xenoph., Symp. 4, 44; por. Xenoph., Symp. 8, 4-6 [= SSR V A 14].

43 Por. DL VII 3 [= SSR V H 38]: „Zénón bol vo všetkom horlivým nasledovníkom Kratétovej filozofie, ale jediné, pred čím sa zdráhal, bola kynická bezostyšnost’. Aby ho učitel’ vyliečil aj z tohto neduhu, dal mu niest' hlinenú misu šošovice cez aténsku štvrt' Kerameikos, v ktorej bývali hrnčiari. Ked' Kratés videl, ako sa pri tom Zénón hanbí a zakrýva si tvár, udrel do misy palicou a tá sa rozbila na márne kúsky. Šošovica sa z nej sypala Zénónovi pod nohy a on sa snažil od hanby utiect' kade lahšie. Vtedy mu Kratés povedal: Prečo sa snažís utiect' preč, ty malý Fenićanko? Nič zlé sa ti predsa nastalo." Na okraj tejto anekdoty by sme mali poznamenat, že práve v Kerameiku začínala posvätná cesta z Atén do Eleusíny, po ktorej putovali v procesii účastníci tamojších mystérií. Kratés mohol teda parodizovat práve túto procesiu, pričom vážnou stránkou tejto paródie je Zénónova iniciácia do „mystériî“ kynického života. Prostriedkom tejto iniciácie je utrpená hanba, ktorú má adept prekonat'. Je šitá na mieru pre Zénóna, ktorému chýba práve schopnoste čelit hanbe. Zénón je v rozpakoch už z toho, že musí niest’ plný hrniec. Dôvodom môže byt to, že šošovičná kaša bola vnímaná ako symbol kynického života (SSR V H 72), niest̉ teda hrniec kaše znamenalo verejne sa priznat k tomuto životnému štýlu spojenému s bezostyšnostou.

44 DUTSCH, D. Dog-love-dog..., s. 254.

45 DL VI 72 [= SSR V B 353]. 
aby sa sama rozhodla, teda uviedla do praxe spomínaný podstatný princíp kynickej sexuálnej morálky. Okrem toho Diogenés v tom istom zlomku hovorí, že ženy majú byt' „spoločné“ (кoเvaí), to znamená, že nemajú byt považované za majetok manžela. Opät ide o postoj tak nezvyčajný pre gréckeho človeka

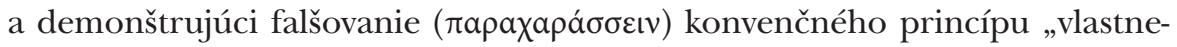
nia“ životnej partnerky. Tomu nasvedčuje aj skutočnosṫ, že v epizóde z Hip-

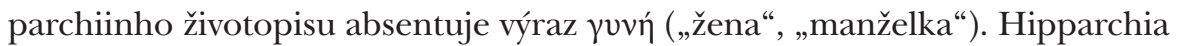

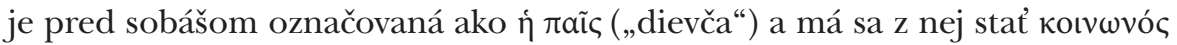
(„spoločníčka“, azda „družka“), teda tá, ktorá zdiel’a spoločný spôsob života.

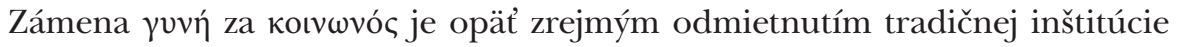
manželstva, frapantným príkladom - prinajmenšom pre konzervatívne okolie - šokujúceho falšovania obeživa.

Konečne prichádzame k avizovanej analýze druhej časti nášho zlomku ( $D L$ VI 97, 3 - 98, 7), kde Hipparchia vystupuje ako samostatná kynická filozofka. ${ }^{46} \mathrm{~V}$ nasledujúcej časti teda ukážeme, ako vyzerala filozofka Hipparchia v „akcii“ a čím si mohla za svoje filozofovanie zaslúžit slávu a nesmrtel’nost'. Podla nášho doxografa to, čo ju najlepšie charakterizuje v tejto role, je jej pohotovost’ v reči prepájaná s praktickým gestom. Anekdota sa odohráva

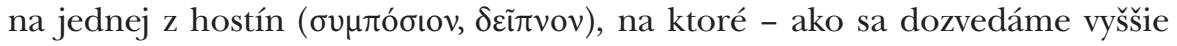
(DL VI, 97, 2) - mala Hipparchia chodievat’ spolu s Kratétom. Zdá sa, že aténska vyššia spoločnost’ zvykla pozývat kynických filozofov, pravdepodobne aby oživili tieto večierky svojským ostrovtipom, a tí to zas využívali na propagáciu svojich názorov. Prípadne sa kynici na tieto podujatia mohli „pozývat" aj sami od seba, ako provokatéri a „špehovia nenásytnosti“ pyšných l’udí. ${ }^{47}$ Známa je napríklad anekdota o Diogenovi, ktorému na takejto hostine hádzali kosti ako psovi a on sa pri odchode ako správny pes na svojich hostitelov vymočil. ${ }^{48}$

Theodóros z Kyrény (okolo 340 - okolo 250 pred Kristom), s ktorým sa mala Hipparchia dostat do slovnej výmeny, bol známy predstavitel' kyrénskej školy, žiak Aristippa Métrodidakta (vnuka známejšieho Sókratovho žiaka Aristippa), ktorý si pre svoje útoky proti tradičnému náboženstvu vyslúžil

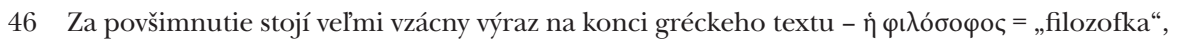
„filozof v ženskom rode“. O filozofických implikáciach tohto jazykového výrazu sme rozvinuli úvahu na začiatku časti 1.

47 Por. $D L$ VI 45 [= SSR V B 27].

$48 D L$ VI 46 [= SSR V B 146]. Diogenés na hostine sa objavuje aj v zlomkoch SSR V B 55, 192, 412 . 
prezývku „Bezbožník“ (ó å $\theta \varepsilon o \varsigma){ }^{49}$ Aby sme priblížili Hipparchiin filozofický výkon, ktorý sa prejavil v konfrontácii s Theodorom, musíme uviesṫ zopár myšlienok tohto filozofa, ako ich nachádzame $\mathrm{v}$ Diogenovom diele. Tento životopisec okrem iného uvádza aj argument, ktorým mal Theodóros obhajovat tvrdenie, že ak sa odstráni falošný predsudok o činoch ako krádež, cudzoložstvo či svätokrádež, ktoré sa zvyknú považovat’ za hanebné, žiaden z týchto skutkov nie je zlý vo svojej podstate. Mudrc preto môže dat volný priebeh aj svojim sexuálnym pudom. Diogenes Laertský konkrétne píše:

Mudrc sa [podla Theodóra] môže bez všetkých škrupúl venovat svojim milostným vášňam a svoje počínanie bude hájit týmito argumentami: „Môže byṫ žena, vzdelaná v gramatike, užitočná, pretože je vzdelaná v gramatike?“ „Áno.“ „Môže byt chlapec alebo mladík, vzdelaný v gramatike, užitočný, pretože je vzdelaný v gramatike?“ „Áno.“ „Môže byt teda krásna žena užitočná, pretože je krásna, a tak isto krásny chlapec alebo mladík môže byt užitočný, pretože je krásny?“ „Áno.“ „Je teda užitočný, pre styk s ním?" Ak sa pripustia tieto veci, robí z toho d’alší záver: „Ak sa niekto stýka s niekým, pretože je to užitočné, nedopúšta sa nijakej chyby, a tak isto sa nedopustí nijakej chyby, ak bude používat krásu, pretože je to užitočné.“ Takýmito a podobnými argumentmi upevňoval svoje tvrdenia..$^{50}$

Vidíme, že Hipparchia v našom zlomku tento argument paroduje a ukazuje, že po dosadení iných premenných sa výsledok stane pre Theodóra nepohodlným. Ak smieme predpokladat, že citovaný Theodórov argument zaznel v kontexte hostiny u Lysimacha a Hipparchia reagovala práve naň (pričom Diogenés Laertský oba argumenty oddelil a jeden uviedol v životopise Theodóra, druhý v životopise Hipparchie), potom filozofka dáva najavo, že odmieta považovat ženu (či chlapca) iba za použitel'ný sexuálny predmet. To je pre ňu rovnako neprijatelné ako pre Theodóra byt iba fackovacím panákom.

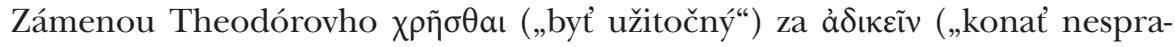
vodlivo“) dáva filozofka najavo, že „používanie“ druhej osoby ako nástroja

49 Diogenés Laertský venuje Theodórovi záver kapitoly o kyrenaikoch v II. knihe Životopisov (DL II 98-104). Z tohto prameňa vyberáme niekol'ko faktov. Predovšetkým nepoznáme dôvod, prečo bol Theodóros poslaný z rodnej Líbye (mesto Kyréne) do vyhnanstva, vieme však, že sa na čas usadil v Aténach. Odtial' však uteká preč, pretože mal čelit súdu za bezbožnost', a v Alexandrii vstupuje do služieb Ptolemaia I. Sótéra. Ako jeho vyslanec prichádza na dvor Alexandrovho diadocha Lysimacha, ktorý v roku 306 pred Kristom prijal titul „krála“ ( $\beta a \sigma ı \lambda \varepsilon v ́ \varsigma)$ a vládol v Thrákii, Makedónsku a Malej Ázii. Ten bol podla nášho zlomku hostitel’om večierka, na ktorom došlo k stretnutiu medzi Theodórom a Hipparchiou. 
znamená dopúštat’ sa nespravodlivosti. V pozadí akiste stojí kynická sexuálna etika, ktorá považuje sexuálny akt za prípustný iba na základe vzájomného súhlasu a pri všetkej úcte $\mathrm{k}$ individuálnej osobnosti sexuálneho partnera. Je to vel'mi moderný a z hl'adiska ženy značne emancipačný postoj, ktorý navyše Hipparchia zargumentovala vel'mi obratným spôsobom.

Theodóros reaguje na Hipparchiin elenchos tak, že gestom a slovami vnúti prítomným svoju pôvodnú pozíciu: Hipparchia je len žena a jej miesto je inde ako pri filozofickom rozhovore. Pre neho je len objektom a cielom mužskej túžby, nie nositelom autonómneho rozhodnutia či subjektom schopným filozofickej úvahy. Robí to gestom i slovom. Obnaží Hipparchiu, čím odhalí jej ženskost’ a zároveň ju prezentuje ako sexuálny predmet. Gesto strhnutia -

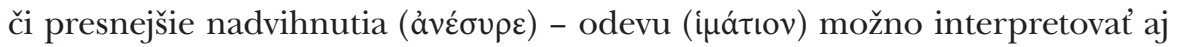
metonymicky ako pozbavenie autority. V Aristofanovej komédii Ženský snem ženy zoberú svojim manželom himatia, aby mohli samy vystupovat ako tie, čo majú vládu nad obcou. Blepyros sa tu vo verši 333 stažuje, že musí nosit ženské šaty, lebo nevie nájsţ svoje himation..$^{51}$ Použitie slova himation v súvislosti s Hipparchiou len posilňuje narážku na tento kontext, pretože očakávat by sa u nej dal skôr obnosený kynický plášṫ (tribón). Filozoficky vel'avravná je aj Hipparchiina reakcia na strhnutie odevu: „hoci bola žena, vôbec sa nezlakla ani nezahanbila“ (VI, 97). Táto odpoved’ je krásnym príkladom typicky kynického postoja emancipovanej ženy. Odpoved’ je totiž daná na úrovni praktického životného postoja neotrasitelnej ženy zbavenej tradičnej hanblivosti, s ktorou počítal Theodóros. ${ }^{52}$

Ked' prvý Theodórov plán diskreditácie Hipparchie nevyšiel, citátom z Euripidových Bakchantiek (1236) prezentuje jej odmietnutie zostat’ doma a priast' (tradičné zamestnanie ženy) ako čosi obludné. V Euripidovej tragédii tieto slová hovorí Pentheova matka Agaué, ked'sa vrátila z extatického sprievodu šalejúcich mainád, pri ktorom roztrhala zaživa telo vlastného syna, v domnienke, že to bol horský lev. Stále v rituálnom ošiali sa Agaué chváli svojmu otcovi, že zanechala krosná, aby vykonala väčšie veci. Theodóros touto narážkou podsúva, že Hipparchiino angažovanie sa vo filozofii je šialené a obludné zároveň, pretože ide o opustenie prirodzeného miesta, ktoré je

51 O vztahu medzi touto Aristofanovou komédiou a Platónovou Ústavou por. JINEK, J. Die beste Staatsverfassung zwischen Komik und Ernst...

52 Hipparchiino nezahanbenie sa po strhnutí šiat by sme mohli klasifikovat ako prípad tzv. praktickej chreie. Por.: „Chreia je krátky výrok alebo čin, ktorý vyjadruje nejakú pointu

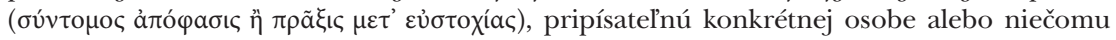
osobe podobnému“ (Theon, Progymn. 96, 19-21). 
určené ženám..$^{53}$ Hipparchiina odpoved' je naopak vel'mi triezva a racionálna.

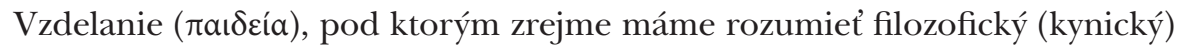
spôsob života, je pre ňu cennejšie než venovanie sa ženským povinnostiam diktovaným konvenciou, ktorú opät kynická filozofka znehodnocuje a falšuje. Ked’že pre kynikov nie je ciel'om pravdivé poznanie sveta a vecí, „vzdelanie“, o ktorom tu hovorí Hipparchia, sa musí týkat subjektu ako nositela morálnej vôle. ${ }^{54}$ Táto kynická „paideia“ sa v konečnom dôsledku prejavuje aj v príkladnej lahostajnosti, s akou zniesla svoje obnaženie. Možno chce naznačit že práve vd’aka tomu, že odmietla tkat’, získala drahocenné poznanie životnej (samozrejme kynickej) filozofie, ktorá jej umožnila nereagovat na akt zahanbenia pri násilnom obnažení jej tela. Ide o zrkadlový obraz Kratétovho obnaženia pri scéne „psieho sobáša“ a Hipparchia tu bravúrne ukazuje, že vo filozofickom spôsobe života prevyšuje dokonca mužských filozofov. Nielen Theodóra, ale napríklad aj Zénóna. ${ }^{55}$ Nejako takto sa teda Hipparchia stala slávnou filozofkou.

\section{Záver}

V predloženej štúdii sme sa pokúsili ukázat’, v čom je osobnost̉ najznámejšej filozofky staroveku Hipparchie výnimočná a inšpiratívna. Obraz, ktorý nám o nej zachovala sókratovská literatúra, je v podstate vel’mi moderný a môže byṫ predmetom mnohodimenzionálnej - historickej, sociologickej, psychologickej či dokonca feministickej - reflexie. Hipparchiina filozofia sa v duchu kynickej tradície neodohráva na poli teórie, ale životnej praxe. Tá je sympaticky rámcovaná typicky „ženskou“ tematizáciou - sférou manželstva a poslania ženy v partnerskom zväzku. Ved’ Hipparchia bola jedna z prvých, ak nie úplne prvá, žena, ktorá sa úspešne vzoprela zaužívaným konvenciám obce, teda toho, čo sa „patrí“, čo je „bežné“ a slušné. Do manželstva s Kratétom ju nepriviedla povinnost’ priniest’ zdarné potomstvo pre štát či manžela, bohatstvo či krása ženícha alebo neodolatelná túžba po zmyslovej rozkoši. Všetky tieto petrifikované kultúrne konštanty typicky „kynicky“ falšuje a subvertuje. Boli to slová a filozofická reflexia a nie majetok a ekonomické

53 Por. označenie Diogena za „šalejúceho Sókrata“ v zl. SSR V B 59; FLACHBARTOVÁ, L. Diogenouský kynizmus..., s. 95-160; FLACHBARTOVÁ, L. Diogenes of Sinope..., s. 308-350.

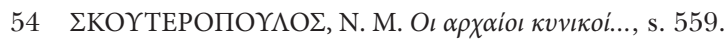

55 DUTSCH, D. Dog-love-dog..., s. 254-255. 
zabezpečenie, ktoré ju pútajú k ženíchovi. Bolo to intelektuálne dobrodružstvo a nie zmyselná zaslepenoste, ktorá sa stáva pojivom manželského zväzku. Hipparchia chce štastne žit’ a nie zabezpečene prežívat'. Kynicky a prekvapivo vel'mi „moderne“ sa obracia aj polarita medzi partnermi: je to Kratés, a nie Hipparchia, ktorý ponúka partnerke svoje telo, a je to ona, ktorá má právo slobodne sa preň rozhodnút a disponovat ním. Celkom jasne tu vidíme zrod emancipácie a zrovnoprávnenia ženy s mužom, ktorých manželstvo sa stáva skutočným partnerstvom, či dokonca priatelsstvom. Príbeh Kratéta a Hipparchie je v mnohom diachronický a inštruktívny aj pre modernú reflexiu. Azda je rozvinutím platónskeho filozofického eróta v praktickej rovine l’udskej existencie. Ak sme v príbehu o tom, ako sa Hipparchia stala vel'kou filozofkou, zbadali seba samých, potom štúdia zaslúžene dospieva ku cielu.

\section{Zoznam použitých zdrojov}

BRANHAM, Robert Bracht. Defacing the Currency: Diogenes' Rhetoric and the Invention of Cynicism. In BRANHAM, Robert Bracht - GOULET-CAZÉ, MarieOdile (eds.). The Cynics: The Cynic Movement in Antiquity and its Legacy. Berkeley, CA: University of California Press 1996, s. 81-104.

DIOGENES LAERTIUS. Životopisy slávnych filozofov. 2 zv. Preklad Miloslav OKÁL. Bratislava: Vydavatel'stvo Slovenskej akadémie vied 1954.

DIOGENES LAERTIUS. Lives of Eminent Philosophers. Tiziano DORANDI (ed.). Cambridge: Cambridge University Press 2013.

DIOGENES LAERTIUS. Lives of the Eminent Philosophers. James MILLER (ed.). Preklad Pamela MENSCH. Oxford: Oxford University Press 2018.

DUTSCH, Dorota. Dog-love-dog: Kynogamia and Cynic sexual ethics. In MASTERSON, Mark - SORKIN RABINOWITZ, Nancy - ROBSON, James (eds.). Sex in Antiquity. Exploring Gender and Sexuality in the Ancient World. Abingdon - New York: Routledge 2015, s. 245-259.

FLACHBARTOVÁ, Lívia. Diogenes of Sinope as Socrates mainomenos. In SUVÁK, Vladislav (ed.). Antisthenica Cynica Socratica. Praha: OIKOYMENH 2014, s. 308-350.

FLACHBARTOVÁ, Lívia. Diogenouský kynizmus ako spôsob života. Prešov: Filozofická fakulta Prešovskej univerzity 2015.

FOUCAULT, Michel. Subjectivity and Truth. Lectures at the Collège de France 1980-1981. Translation Graham BURCHELL. London: Palgrave Macmillan 2017.

GIANNANTONI, Gabriele (ed.). Socratis et Socraticorum reliquiae. 4 zv. Napoli: Bibliopolis 1990 .

GOULET-CAZÉ, Marie-Odile. Une liste de disciples de Cratès le Cynique en Diogène Laërce 6, 95. Hermes. 1986, 114(2), s. 247-252.

JINEK, Jakub. Die beste Staatsverfassung zwischen Komik und Ernste. Bemerkungen zu Aristophanes Ekklesiazusai und Platons Politeia, Buch V. In JINEK, Jakub - 
KONRÁDOVÁ, Veronika (eds.). For Friends, All Is Shared. Friendship and Politics in Ancient Greek Political Thought. Praha: OIKOYMENH 2016, s. 44-59.

KALAŠ, Andrej. Vplyv kynizmu na stoicizmus. Filozofia. 2002, 57(6), s. 405-430.

KALAŠ, Andrej. Diogenov postoj k l'udskej sexualite: hedonizmus, alebo asketizmus? Filozofia. 2016, 71(2), s. 119-130.

MAIER, Heinrich. Sokrates. Sein Werk und seine geschichtliche Stellung. Tübingen: Verlag von J. B. C. Mohr 1913.

MEJER, Jørgen. Diogenes Laertius and his Hellenistic Background. Wiesbaden: Franz Steiner Verlag 1978. Hermes - Einzelschriften, Heft 40.

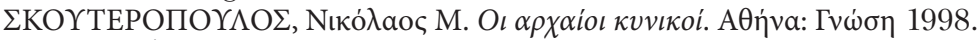

ZELINOVÁ, Zuzana. Kynická paideia alebo Antisthenés medzi Odysseom a Sókratom. Filozofia. 2016, 71(2), s. 107-118.

ZELINOVÁ, Zuzana. Paideia v sokratovskej filozofii. Bratislava: Univerzita Komenského v Bratislave 2018.

ZELLER, Eduard. Die Philosophie der Griechen in ihrer geschichtlichen Entwicklung dargestellt. II 1: Sokrates und die Sokratiker. Plato und die alte Akademie. Leipzig: Reisland ${ }^{5} 1922$.

\section{prof. Vladislav Suvák, PhD.}

Inštitút filozofie, Filozofická fakulta PU v Prešove

17. novembra 1, 08001 Prešov, Slovenská republika

vladislav.suvak@gmail.com

\section{Mgr. Jaroslav Cepko, PhD.}

Katedra filozofie, Filozofická fakulta, Univerzita Mateja Bela Tajovského 40, 97401 Banská Bystrica, Slovenská republika jaroslav.cepko@umb.sk

\section{doc. Andrej Kalaš, PhD.}

Katedra filozofie a dejín filozofie, Filozofická fakulta, Univerzita Komenského v Bratislave Šafárikovo nám. 6, 81499 Bratislava, Slovenská republika andrej.kalas@uniba.sk 
